\title{
岐阜薬科大学における臨床系教員の臨床能力維持と臨床研究
}

\author{
舘知 也, * ${ }^{*}$ 野口 義 紘, 寺町ひとみ
}

\section{Maintenance of Clinical Expertise and Clinical Research by the Clinical Professors at Gifu Pharmaceutical University}

\author{
Tomoya Tachi, ${ }^{*}$ Yoshihiro Noguchi, and Hitomi Teramachi \\ Laboratory of Clinical Pharmacy, Gifu Pharmaceutical University; 1-25-4 Daigakunishi, Gifu 501-1196, Japan.
}

(Received August 18, 2016)

\begin{abstract}
The clinical professors at Gifu Pharmaceutical University (GPU) provide pharmaceutical services at GPU Pharmacy, Gifu University Hospital, and Gifu Municipal Hospital to keep their clinical skills up-to-date; they also perform clinical research in collaboration with many clinical institutes. The Laboratory of Clinical Pharmacy is part of the Department of Pharmacy Practice and Science, to which the clinical professors belong, and is composed of three clinical professors (a professor, an associate professor, and an assistant professor). The professor administers the GPU Pharmacy as its director, while the associate professor and assistant professor provide pharmaceutical services to patients at Gifu Municipal Hospital, and also provide practical training for students in the GPU Pharmacy. Collectively, they have performed research on such topics as medication education for students, clinical communication education, and analysis of clinical big data. They have also conducted research in collaboration with clinical institutes, hospitals, and pharmacies. Here, we introduce the collaborative research between the Laboratory of Clinical Pharmacy and Gifu Municipal Hospital. These studies include "Risk factors contributing to urinary protein expression resulting from bevacizumab combination chemotherapy", "Hyponatremia and hypokalemia as risk factors for falls", "Economic evaluation of adjustments of levofloxacin dosage by dispensing pharmacists for patients with renal dysfunction", and "Effect of patient education upon discharge for use of a medication notebook on purchasing over-the-counter drugs and health foods". In this symposium, we would like to demonstrate one model of the association and collaborative research between these clinical professors and clinical institutes.
\end{abstract}

Key words_ clinical professor; clinical expertise; clinical research; collaborative research

\section{1. はじめに}

2006 年度から 6 年制薬学教育が開始し，ちょう ぞ 10 年になる。当時, 医療現場で臨床業務を行っ てきた薬剤師が，臨床系教員（実務家教員）として 大学に移つたが，その多くが医療現場での臨床業務 を継続していない，それだけでなく，臨床系教員が 有する実務経験を生かした研究にも時間を費やすこ とができていないのが現状である.

時代の変遷とともに，医療における薬剤師の役割 は変化している，その中で，臨床系教員が大学にお ける薬剤師の養成・育成を担うには，臨床系教員が

岐阜薬科大学病院薬学研究室（干501-1196 岐阜市大学 西 1-25-4)

*e-mail: tachi@gifu-pu.ac.jp

本総説は, 日本薬学会第 136 年会シンポジウム S19 で 発表した内容を中心に記述したものである.
現在の医療に携わり，その知識及び経験を有してい る必要がある．また，臨床を継続してこそ，臨床に 直結した医療薬学研究を行うことができると考え る. つまり, 臨床系教員には, 教育, 実務及び研究 の両立が求められる.

求められる臨床系教員として, 教育, 実務及び研 究の観点から, 以下の (1)から (3)が必須であると考 える.

（1）薬学教育モデル・コアカリキュラムの全体 像の理解

（2）現在の医療を伝える臨場感あふれる薬学教 育

（3）臨床に直結した医療薬学研究

臨床系教員は, 薬学教育を担う立場として薬学教 育モデル・コアカリキュラムの全体像を理解し，現 在薬剤師が行っている臨床業務に携わり，実務経験 


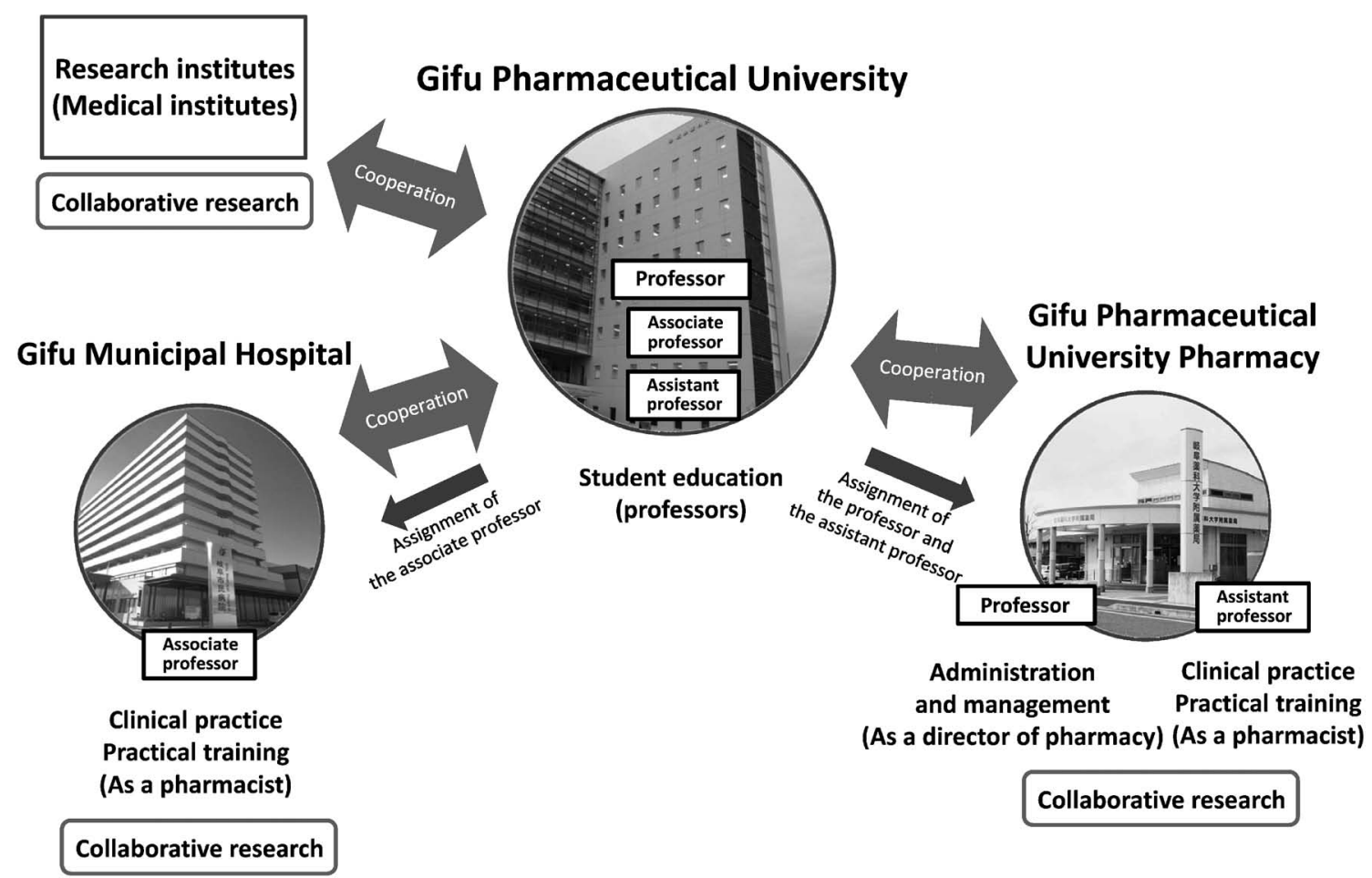

Fig. 1. Organization Diagram of the Laboratory of Clinical Pharmacy in Gifu Pharmaceutical University on August 1, 2016

を積み, 現在の臨床業務及び実務経験に基づいた, 臨場感あふれる薬学教育を行わなければならない。 さらに, 現場の薬剤師と協力して, 医療薬学領域の 新規エビデンスを構築するとともに, 学生に, 薬剤 師が行う医療薬学研究を指導することが求められる.

岐阜薬科大学では, 臨床系教員は教育, 実務及び 研究の両立を目指し, 常に研鑽を積み, 時代が求め る薬剤師を養成・育成し, 医療薬学研究に関する発 表・報告を数多く行ってきた. 本誌上シンポジウム では, 岐阜薬科大学における臨床系教員の臨床能力 維持と臨床研究について紹介する.

\section{2. 岐阜薬科大学における臨床系教員の臨床能力} 維持と臨床研究

岐阜薬科大学では, 臨床系教員は実践薬学大講座 に所属している。実践薬学大講座は, 病院薬学研究 室（教授 1 名, 講師 1 名, 助教 1 名), 薬局薬学研 究室 (講師 2 名, 助教 2 名), 医薬品情報研究室 (教授 1 名), 及び実践社会薬学研究室（教授 1 名, 准教授 1 名, 助手 1 名）から構成され（2016 年 8 月 1 日現在), そのほとんどの教員がおおよそ 5 年 以上の薬剤師としての経験を有している. 実践薬学 大講座の多くの教員が臨床現場を兼務することに なっており, 現在, 岐阜薬科大学附属薬局, 岐阜大
学医学部附属病院及び岐阜市民病院において臨床業 務を行い，臨床能力を維持するよう努めている．ま た, 実践薬学大講座の各研究室は, それらの機関だ けでなく多くの医療機関と連携して臨床研究を行っ ている.

筆者が所属する実践薬学大講座の病院薬学研究室 には, 教授, 講師, 助教の 3 人の教員がおり, 大学 で学生教育を行うだけでなく, 教授は岐阜薬科大学 附属薬局の薬局長として薬局の管理・運営を行い, 講師は岐阜市民病院で, 助教は岐阜薬科大学附属薬 局で臨床業務や実務実習に携わっている（Fig. 1). 1)また, 病院薬学研究室では, 医療機関におけ る豊富な実務経験を生かすことにより，『「医薬品の 正しい使い方」教育』, 『医療コミュニケーション』, 『医療ビッグデータの解析』, 及び『臨床におけるエ ビデンスの確立』のテーマについて研究を行ってい る.『医薬品の正しい使い方」教育』では，国民一 人ひとりが「医薬品を正しく使う」ことができるよ うになることを目的として, 中学校保健体育科の授 業プログラムを始めとした, 児童生徒, 保護者, 地 域住民を対象とした包括的くすり教育プログラムの 構築に関する研究を進めている. ${ }^{2-4)}$ 『医療コミュニ ケーション』では, 薬剤師や薬学生が患者と応対す 
る場合，どのようなスキルが必要であるのか，ある いは，薬学生が実習後にどのようなスキルが修得で きたかについて評価するために測定尺度（薬剤師の コミュニケーションスキル測定尺度 Teramachi's Pharmacist Communication Skill Scale; TePSS-31, 薬剤師のがん患者応対に必要とされるコミュニケー ションスキル測定尺度 Teramachi \& Komada's Pharmacist Cancer Communication Skill Scale; Topic-29）を開発し，それらの尺度を活用した研究を 行っている. 5,6) 『医療ビッグデータの解析』では, 医薬品適正使用のために，独立行政法人医薬品医療 機器総合機構 (Pharmaceuticals and Medical Devices Agency; PMDA) の医薬品副作用データベー スである Japanese Adverse Drug Event Report database（JADER）やアメリカ食品医薬品局（Food and Drug Administration; FDA) の医薬品副作用 データベースである FDA Adverse Event Reporting System（FAERS）を始めとした医療ビッグデータ の薬剤疫学的手法を用いた解析を行っている. ${ }^{7-10)}$ また，『臨床におけるエビデンスの確立』では，多 くの医療機関と共同して医療現場における調查研究 を行い（Fig. 1)，臨床的な問題点の抽出及びその 解明とともに，新たなエビデンスの確立を目指して いる. ${ }^{11-28)}$

\section{3. 病院薬学研究室の岐阜市民病院薬剤部との連} 携及び共同研究

病院薬学研究室の岐阜市民病院薬剂部との連携及 び共同研究について述べる。岐阜市民病院では各期 に実務実習生を受け入れているが，薬剤部の指導薬 剂師は病院薬学研究室の教員と協力して実習指導を 行っている. また, 共同研究として, 疫学的, 医療 経済学的及び社会科学的手法を利用して幅広い分野 の臨床薬学研究を実施している.ここでは, 病院薬 学研究室の岐阜市民病院薬剂部との共同研究とし て，「ベバシズマブ投与患者における尿タンパク発 現のリスク因子」, ${ }^{21)} 「$ 低ナトリウム血症及び低カリ ウム血症が転倒に及ぼす影響」，22）「腎機能低下患者 におけるレボフロキサシン調剤時の処方監査に対す る経済評価」, ${ }^{23,24)}$ 及び「OTC 薬・健康食品等購入 時におけるお薬手帳利用を目指した患者教育の効 果」25)について紹介する.

3-1. ベバシズマブ投与患者における尿タンパク 発現のリスク因子 ベバシズマブは治癒切除不能
な進行・再発の結腸・直腸がん，非小細胞がんなど の標準的な化学療法に併用され，その有効性が示さ れている. ${ }^{29,30)}$ 副作用としてタンパク尿の発現頻度 は 30-40\% と報告されているが, ${ }^{31)}$ そのリスク因子 について明らかにされていない。 そこで，ベバシズ マブ併用化学療法による尿タンパク発現のリスク因 子を明らかにするために, 後ろ向きコホート調査を 行つた. ${ }^{21)}$

2010 年 2 月から 2011 年 2 月の間に岐阜市民病院 でベバシズマブ併用化学療法を施行した 20 歳以上 の患者 47 人を対象とした。除外基準により解析対 象患者数は 34 人となり，尿タンパクが発現しな かった患者は 24 人 $(70.6 \%)$, タンパク尿が発現し た患者は 10 人 $(29.4 \%)$ であった。単変量解析の 結果, 体重当たりの投与量, 空腹時血糖值について 尿タンパク非発現群と尿タンパク発現群で有意な差 が認められた $(p<0.05)$ 。多変量解析の結果，収縮 期血圧（130 mmHg 以上）[オッズ比 (OR)；14.50, 95\%信頼区間（CI）；1.326-158.6, $p=0.028]$ につ いて有意な差が認められた。以上より，収縮期血圧 （130 mmHg 以上）がベバシズマブ併用化学療法に よる尿タンパク発現のリスク因子であることが明ら かになった。

3-2. 低ナトリウム血症及び低カリウム血症が転 倒に及ぼす影響転倒事故は患者の QOL，activity of daily life (ADL) の低下, 疾病の回復遅延をも たらすため，医療機関では転倒事故防止の対策が重 要となっている。転倒のリスク因子として年齢, 疾 病，服用薬剤などが報告されているが, ${ }^{32)}$ 低ナトリ ウム血症及び低カリウム血症が転倒に及ぼす影響に 関する報告はない。そこで，低ナトリウム血症及び 低カリウム血症が転倒に及ぼす影響について明らか にするために，後ろ向きコホート調査を行つた. ${ }^{22)}$

2012 年 5 月から 2013 年 4 月の間に，岐阜市民病 院で 3 日以上入院した 18 歳以上の患者 3242 人を調 查対象とした。除外基準により，解析対象患者数は 2948 人となり，そのうち転倒群は 97 人 $(3.3 \%)$, 非転倒群は 2851 人 $(96.7 \%)$ であった。低ナトリ ウム血症の患者は，転倒群で 18 人 $(18.6 \%)$, 非転 倒群で 275 人 $(9.6 \%)$, 低カリウム血症の患者は, 転倒群で 18 人 $(18.6 \%)$, 非転倒群で 224 人（7.9 \%) であり，ともに転倒群及び非転倒群の間に有意 な差が認められた $(p<0.05)$ 。単変量解析の結果, 
年齢 65 歳以上，低ナトリウム血症，低カリウム血 症, 中枢神経系疾患, 循環器疾患, 未梢神経 - 筋疾 患，転倒リスク増大薬の服用及び催眠鎮静薬の増量 について転倒群と非転倒群間で有意な差が認められ た $(p<0.05)$. 多変量解析の結果, 年齢 65 歳以上 [OR; $2.180,95 \% \mathrm{CI} ; 1.242-3.826, p=0.007]$, 低ナ トリウム血症 [OR; 1.751, 95\% CI; 1.020-3.005, $p=$ $0.042]$ ，低カリウム血症 [OR; $2.209,95 \% \mathrm{CI} ; 1.280-$ $3.813, p=0.004]$ ，及び中枢神経系疾患 [OR; 2.492 , 95\% CI；1.629-3.814, $p<0.001]$ について有意な差 が認められた，以上より，低ナトリウム血症及び低 カリウム血症が入院中の転倒リスクを高めることが 明らかになった。

3-3. 腎機能低下患者におけるレボフロキサシン 調剂時の処方監査に対する経済評価岐阜市民病 院薬剂部では，2011 年 4 月より，薬剤師が，腎排 泄型薬剤の調剤時に各患者の血清クレアチニン值を 電子カルテで調査し，腎機能を評価するとともに, 適正な投与量及び投与間隔を医師に提案する取り組 みを行ってきた。本研究では，レボフロキサシンで の調剂時処方監査の取り組みが副作用の発現及びそ の関連費用に及ぼす影響を調査し, ${ }^{23)}$ また，調剤時 処方監査において消費する薬剤師及び医師の時間や 費用を調査した. ${ }^{24)}$ それらの結果を基に，レボフロ キサシンでの調剂時処方監査の取り組みの経済評価 として医療機関の立場から網羅的に総医療資源費用 の分析を行った. ${ }^{24)}$

2011 年 3 月から 2011 年 8 月の間に, 岐阜市民病 院において 75 歳以上でレボフロキサシンが処方さ れた患者を対象に，薬剤部の薬剤師による調剤時処 方監査を行つた群を処方監査群とし，通常の処方監 査を行つた群を対照群とし，レボフロキサシンによ る副作用及び関連費用を評価した。レボフロキサシ ンによる副作用発現率は，対照群に比べて処方監査 群で有意に低かった（それぞれ，13.3\%，4.2\%， $p=0.028)$.また, 処方監查群において減量したレ ボフロキサシンの費用は 191.1 円/人，副作用に関 する治療及び検査の費用は 15.5 円/人，対照群にお いてはそれぞれ 0 円/人，290.0 円/人であった。ま た，薬剤師及び医師に対するアンケート調査を行っ た結果，薬剂師及び医師において，患者 1 人あたり のレボフロキサシンでの人件費換算費用の増加分は それぞれ，198.6 円/人及び 208.8 円/人であった.
以上より，患者 1 人あたりの総医療資源費用の削減 分は 58.2 円/人であることが分かった.

\section{3-4. OTC 薬・健康食品等購入時におけるお薬} 手帳利用を目指した患者教育の効果医療機関間 で薬剤情報を共有する手段としてお薬手帳が評価さ れている．医療用医薬品のお薬手帳による薬歴管理 は行われているが，一般用医薬品（OTC 薬）や健 康食品・サプリメント（健康食品等）に関する情報 のお薬手帳による薬歴管理はほとんど行われていな い. 33) そこで，OTC 薬や健康食品等購入時におけ るお薬手帳利用を目指した退院時患者教育の効果を 明らかにするために，ランダム化比較試験を適用し 入院患者の退院時に介入群と対照群に割り付けを行 い，退院前と退院後に OTC 薬 ・健康食品等購入時 におけるお薬手帳の利用状況を比較した。 ${ }^{25)}$

岐阜市民病院眼科に入院中で 20 歳以上の患者 を，教育を行う介入群と行わない対照群にランダム 割り付けし，退院指導前と退院 2 カ月後にアンケー 卜調査を行った。教育内容は, OTC 薬・健康食品 等購入時のお薬手帳利用の重要性の説明と利用の勧 奨とした。退院指導前における解析対象患者 39 人 の背景及びアンケートの結果から, 介入群と対照群 の間で退院指導前のすべての項目で有意な差は認め られなかった。退院 2 力月後における解析対象患者 39 人のお薬手帳の提示あるいは記載に関する質問 の回答結果から算出された「退院指導前から退院指 導後に OTC 薬あるいは健康食品等の購入時にお薬 手帳を提示するかお薬手帳に記載するようになった 患者の割合」は，介入群で 30.0\% (6/20), 対照群 で 0\%（0/19）であり，介入群で有意に高かった $(p=0.020)$. 以上から，本教育により患者は OTC 薬や健康食品等の購入時にお薬手帳を自発的に利用 するようになったことが明らかになった。

\section{4. まとめ}

このように, 岐阜薬科大学の臨床系教員は, 医療 機関での臨床業務と医療機関との共同研究を通じ て, 臨床能力維持と臨床研究を行い, 教育, 実務及 び研究を両立するよう努めてきた。本誌上シンポジ ウムで紹介した岐阜薬科大学の実例が, 臨床系教員 と医療機関との連携及び共同研究の 1 つのモデルと なれば幸いである。 
市民病院薬剂部の後藤千寿薬剂部長を始め, 薬剂部 の皆様に深く御礼申し上げます。また，共同で研究 を行った病院薬学研究室の学生及び卒業生に感謝い たします。

利益相反＼cjkstart開示すべき利益相反はない.

\section{REFERENCES}

1) Teramachi H., Yakugaku Zasshi, 136, 733736 (2016).

2) Teramachi H., Ohta T., Kohda Y., Kito H., Komada N., Shiga H., Tamura K., Tachi T., Tsuchiya T., Katsuno S., Jpn. J. Pharm. Health Care Sci., 38, 767-779 (2012) .

3) Teramachi H., Saito K., Esaki H., Kato M., Usui K., Noguchi Y., Tachi T., Katsuno S., Jpn. J. Pharm. Health Care Sci., 41, 870-879 (2015).

4) Teramachi H., Tachi T., Saito K., Esaki H., Kato M., Usui K., Noguchi Y., Katsuno S., Jpn. J. Pharm. Health Care Sci., 42, 193-201 (2016) .

5) Teramachi H., Komada N., Tanizawa K., Kuzuya Y., Tsuchiya T., Yakugaku Zasshi, 131, 587-595 (2011).

6) Teramachi H., Komada N., Shiga H., Tamura K., Tsuchiya T., Jpn. J. Pharm. Health Care Sci., 37, 653-660 (2011).

7) Noguchi Y., Esaki H., Asano S., Yokoi T., Usui K., Kato M., Saito K., Tachi T., Teramachi H., Jpn. J. Pharm. Health Care Sci., 41, 488-496 (2015).

8) Noguchi Y., Esaki H., Asano S., Yokoi T., Usui K., Kato M., Saito K., Tachi T., Teramachi H., Jpn. J. Pharm. Health Care Sci., 41, 667-675 (2015).

9) Noguchi Y., Saito K., Esaki H., Usui K., Kato M., Tachi T., Teramachi H., Jpn. J. Drug Inform., 17, 192-198 (2016).

10) Noguchi Y., Yoshida A., Sugiya Y., Hayashi Y., Esaki H., Saito K., Usui K., Kato M., Tachi T., Teramachi H., Jpn. J. Pharm. Health Care Sci., 42, 529-535 (2016) .

11) Mizui T., Teramachi H., Tachi T., Tamura K., Shiga H., Komada N., Umeda M., Koda A., Aoyama S., Goto C., Tsuchiya T., Pharmazie, 68, 706-710 (2013).
12) Teramachi H., Ohta H., Tachi T., Toyoshima M., Mizui T., Goto C., Tsuchiya T., Pharmazie, 68, 909-915 (2013).

13) Tachi T., Goto C., Ono Y., Nagaya K., Koda A., Osawa T., Fukuta M., Tanaka K., Yasuda M., Mizui T., Kobayashi K., Sahashi M., Teramachi H., J. Jpn. Soc. Hosp. Pharm., 50, 7580 (2014).

14) Takahashi T., Teramachi H., Tachi T., Noguchi Y., Nagasawa H., Mizui T., Goto C., Tsuchiya T., Yakugaku Zasshi, 134, 767-774 (2014).

15) Teramachi H., Takahashi T., Tachi T., Noguchi Y., Nagasawa H., Ino Y., Mizui T., Goto C., Tsuchiya T., SAGE Open Med., 2, 2050312114563318 (2014).

16) Tachi T., Goto C., Saito K., Ono Y., Yasuda M., Mizui T., Kobayashi K., Sahashi M., Noguchi Y., Teramachi H., J. Pharm. Commun., 12, 5-10 (2014).

17) Tachi T., Teramachi H., Tanaka K., Asano S., Osawa T., Kawashima A., Yasuda M., Mizui T., Nakada T., Noguchi Y., Tsuchiya T., Goto C., PLoS One, 10, e0124169 (2015) .

18) Tanaka K., Tachi T., Asano S., Osawa T., Kawashima A., Hori A., Yasuda M., Mizui T., Nakada T., Tsuchiya T., Teramachi H., Goto C., Jpn. J. Pharm. Health Care Sci., 41, 515-526 (2015).

19) Tachi T., Yasuda M., Usui K., Umeda M., Nagaya K., Osawa T., Ichihashi A., Noguchi Y., Goto H., Kasahara S., Takahashi T., Goto C., Teramachi H., Pharmazie, 70, 674-677 (2015).

20) Tachi T., Teramachi H., Tanaka K., Osawa T., Noguchi Y., Kawashima A., Nagaya K., Koda A., Hori A., Yasuda M., Mizui T., Goto C., J. Jpn. Soc. Hosp. Pharm., 51, 1455-1461 (2015) .

21) Teramachi H., Shiga H., Komada N., Tamura K., Yasuda M., Umeda M., Tachi T., Goto C., Tsuchiya T., Pharmazie, 68, 217-220 (2013).

22) Tachi T., Yokoi T., Goto C., Umeda M., Noguchi Y., Yasuda M., Minamitani M., Mizui T., Tsuchiya T., Teramachi H., Eur. J. Clin. Nutr., 69, 205-210 (2015).

23) Tachi T., Teramachi H., Asano S., Tanaka K., Fukuta M., Osawa T., Aoyama S., Yasuda 
M., Mizui T., Goto C., Tsuchiya T., Pharmazie, 68, 977-982 (2013).

24) Tachi T., Kato M., Osawa T., Koda A., Fukuta M., Tanaka K., Aoyama S., Yasuda M., Mizui T., Goto C., Teramachi H., Yakugaku Zasshi, 133, 1223-1233 (2013).

25) Tachi T., Tanaka K., Asano S., Yokoi T., Usui K., Kato M., Noguchi Y., Osawa T., Ichihashi A., Yasuda M., Mizui T., Goto C., Teramachi H., Jpn. J. Pharm. Health Care Sci., 40, 632-642 (2014).

26) Tachi T., Yokoi T., Goto C., Umeda M., Yasuda M., Mizui T., Noguchi Y., Teramachi H., Healthy Aging Res., 4, 23 (2015).

27) Tachi T., Teramachi H., Tanaka K., Asano S., Osawa T., Kawashima A., Hori A., Yasuda M., Mizui T., Nakada T., Noguchi Y., Tsuchiya T., Goto C., Springerplus, 5, 327 (2016).

28) Tachi T., Asano S., Goto C., Yoshida T.,
Usui K., Kato M., Yokoi T., Noguchi Y., Tanaka K., Yasuda M., Mizui T., Teramachi H., Jpn. J. Pharm. Health Care Sci., 41, 113120 (2015).

29) Saltz L. B., Clarke S., Díaz-Rubio E., Scheithauer W., Figer A., Wong R., Koski S., Lichinitser M., Yang T. S., Rivera F., Couture F., Sirzén F., Cassidy J., J. Clin. Oncol., 26, 2013-2019 (2008).

30) Reck M., von Pawel J., Zatloukal P., Ramlau R., Gorbounova V., Hirsh V., Leighl N., Mezger J., Archer V., Moore N., Manegold C., J. Clin. Oncol., 27, 1227-1234 (2009).

31) Iwasa S., Kato K., Frontiers in Colorectal Cancer, 1(3) , 40-45 (2008).

32) Suzuki T., Jpn. J. Geriat., 40, 85-94 (2003).

33) Shiga H., Teramachi H., Suzuki H., Komada N., Tamura K., Tachi T., Tsuchiya T., J. Pharm. Commun., 10, 24-35 (2012) . 